\title{
STUDI KASUS IMPLEMENTASI KONSEP DIGITAL MEDIA DAN JURNALIS DIGITAL DI NET.
}

\author{
Veronika \\ Universitas Multimedia Nusantara \\ Scientia Garden, J1. Boulevard Gading Serpong, Tangerang - Banten \\ Email: veronika.kaban@umn.ac.id
}

\begin{abstract}
ABSTRAK
Perkembangan media sosial berpengaruh pada pola konsumsi informasi masyarakat. Data menunjukkan secara global mau pun di Indonesia bahwa angka pengakses informasi melalui media sosial terus meningkat. Sehingga sejumlah media dalam beberapa tahun ini mulai memanfaatkan platform digital seperti website, media sosial dan aplikasi. Dan juga yang turut menjadi perhatian media saat ini adalah medium yang digunakan. Masyarkat mulai tertarik menggunakan perangkat gawainya untuk mengakses internet. Menggunakan metode studi kasus, teknik pengambilan data berupa wawancara dan observasi penelitian ini bertujuan untuk melihat bagaimana ciri tim digital NET. Gambarannya, ciri tim digital NET. Memiliki ciri yang khas sebagaimana konsep digital media milik Flew dan digital journalist dari Malik dan Shapiro. Tiga pilar utama yaitu tim, teknologi dan konten memiliki peran yang besar dalam perkembangan tim digital NET. Fungsi tim digital ini adalah fungsi public relation (kehumasan), fungsi marketing, fungsi promosi. Ditambah juga fungsi siaran yang kental ditemukan pada akun media sosial sejumlah Biro yang dimiliki NET.
\end{abstract}

Kata kunci: digital, journalist, media, televisi

\section{ABSTARCT}

The development of social media has an effect on the pattern of public information consumption. Data shows globally as well as in Indonesia that the number of accessing information through social media continues to increase. So a number of media in recent years began to take advantage of digital platforms such as websites, social media and applications. And also the concern of the media today is the medium used. People are getting interested in using their mobile device to access the internet. Using case study methods, with data collection techniques in the form of interviews and observations of this study aims to see how the characteristics of NET. digital team. In line with Flew's digital media concept and digital journalist concept from Malik and Shapiro. The three main pillars of digital on NET. are team, technology and content which have a big role in the development of the digital NET. team. The function of this digital team are as public relations, as marketing, as promotion functions. And as a broadcasting platform in NET. bureaus team .

Keywords : Digital, journalist, media, television

\section{PENDAHULUAN}

Masyarakat tidak lagi bergantung pada media terdahulu seperti surat kabar, radio dan televisi untuk mendapatkan informasi. Mereka beralih ke platform yang dianggap lebih sederhana dan memudahkan yaitu internet. Ditambah lagi kemudahan mengakses internet melalui perangkat gawai yang artinya bisa mengakses informasi dari mana pun dan kapan pun. Data di berbagai negara menunjukkan bahwa media - media sebelumnya mulai mengambil sikap dengan perubahan teknologi yang merubah kebiasaan masyarakat.
Perubahan pola hidup manusia dipengaruhi oleh teknologi. Salah satu kemajuan teknologi tersebut adalah perkembangan internet yang melesat. Angka pengguna telepon genggam meningkat diikuti angka jumlah pengakses internet yang juga melonjak. Seperti data yang dikeluarkan Asosiasi Penyelenggara Jasa Internet (APJII), pertumbuhan pengguna internet di Indonesia meningkat dari 132, 7 juta pada tahun 2016 menjadi 143, 26 juta ditahun 2017. ( Asosiasi Penyelenggara Jasa Internet, 2018)

Flew (2014) mengungkapkan kita perlu mengakui berapa banyak perubahan 
yang telah terjadi dalam produksi media, distribusi dan konsumsi selama dua dekade terakhir, dan sejauh mana mereka telah dikaitkan dengan transformasi yang lebih luas dalam pekerjaan, gaya hidup, identitas dan budaya, serta ekonomi, politik, urusan global, dan bentuk interaksi sosial. Jika sebelumnya masyakarat mengakses informasi melalui media radio, cetak, televisi dan dengan adanya internet berpindah menggunakan jaringan komputer mau pun melalui perangkat gawai. Kini, dengan kecepatan teknologi internet dan perkembangan platform digital membuat masyarakt tidak lepas dari perangkat gawai mereka. Termasuk dalam hal mendapatkan informasi. data survey APJII tahun 2016 menunjukkan alasan utama mengakses internet adalah update informasi, disusul dengan alasan terkait pekerjaan dan mengisi waktu luang.

Hal ini diikuti dengan sejumlah media massa yang turut memanfaatkan platform digital baik website dan media sosial. Seturut dengan data APJII 2017 yaitu layanan yang paling sering diakses masyarakat Indonesia adalah chatting kemudian media sosial dan search engine. Media sosial menjadi sarana mendapatkan informasi. seperti yang diperoleh sebuah penelitian menunjukkan 88 persen orang muda di Amerika mendapatkan berita dari Facebook dan media sosial lainnya. Bahkan 28 persen dari mereka yang berusia 18 - 24 tahun mengukngkapkan bahwa media sosial adalah sumber informasi atau berita utama mereka. (Clark dan Marchi, 2017)

Tidak hanya itu, jika sebelumnya masyarakat berperan sebagai penikmat informasi kini posisi pembuat dan penerima informasi menjadi kabur. Sebelum ada media sosial komunikasi massa yang dilakukan adalah dari satu pada kelompok besar, satu arah komunikasi, masyarakat yang pasif. Sementara setelah adanya media sosial, karakteristik komunikasinya menjadi mudah diakses, masyakarat yang aktif seperti menyebarkan dan membuat informasi, dan bersifat interaktif. (Adornato, 2017) Tidak jarang informasi pertama sebuah peristiwa diperoleh dari masyarakat yang menyebarkannya melalui media sosial. Kemudian informasi tersebut (bisa berupa data, foto atau video) digunakan media profesional sebagai sumber yang kemudian disiarkan kembali.

Perkembangan ini membuat sejumlah media di dunia beralih atau melebarkan medium yang digunakan dengan platform digital. Tidak terkecuali di Indonesia dan salah satunya adalah media televisi NET. dalam penelitian ini ingin melihat bagaimana media digital dan digital journalismnya diterapkan. Terutama penelitian ini ingin melihat bagaimana televisi beriringan dengan perkembangan digital baik dari medianya mau pun dari sisi jurnalisnya. 
Penelitian sebelumnya dilakukan oleh Mayangsari, Krisdinanto, dan Purnama (2014:112-137). Dengan metode studi kasus, Mayangsari dkk menjelaskan bagaimana dan mengapa implementasi konsep share dan ratting di program YKS, Trans TV. Temuannya adalah bahwa share dan ratting merupakan parameter utama kebijakan program. Artikel ini berusaha menggali bagaimana dan mengapa kerja dari jurnalis digital yang sangat khas dan berbeda dengan jurnalis konvensional. Sebelumnya, akan dibahas dulu beberapa konsep penting dalam artikel ini.

Penelitian lain dengan metode studi kasus dilakukan oleh Thurman dan Walters (2012) dengan judul Live Blogging-Digital Journalism's Pivotal Platform A case study of the production, consumption, and formof live blogs at Guardian.co.uk. Metode kualitatif dengan teknik wawancara pada jurnalis dan editir serta survei pada pembaca, analisis konten, dan mengukur web. Penelitian ini menemukan bahwa live blogs menjadi bagian dari pemberitaan dan penggunaannya yang meningkat untuk menayangkan breaking news.

\section{Konsep Digital Media}

Salah satu cara untuk memahami transformasi digital dari media baru adalah melalui konsep konvergensi, istilah yang banyak digunakan dalam literatur akademis pada media baru, serta dalam diskusi populer. Flew (2014 : 24).
Lev Monich dalam Flew mengusulkan bahwa dalam Bahasa media baru melibatkan sejarah teknologi komputer dan komunikasi yang menyatu, sehingga paduan dari dua sejarah tersebut akan mengarah pada 'terjemahan semua media yang ada ke dalam data numerik yang dapat diakses melalui komputer '. Akibatnya adalah bahwa semua media, dan, semua konten digital, sekarang akan terdiri dari sekumpulan data komputer.

Definisi dari konvergensi media adalah kombinasi dari tiga CS dalam Bahasa Indonesia berarti komputer (teknologi digital media dan informasi), komunikasi (jaringan, peralatan, dan kebiasaan), dan isi (media dan informasi). Mengadopsi pendekatan multiperspektif dan interdisipliner, Meikle dan Young dalam Flew (2014) telah mengusulkan bahwa konvergensi media dapat dipahami sebagai proses pada empat dimensi:

1. Teknologi - kombinasi komputer, komunikasi, dan konten di sekitar platform media digital.

2. Industri - keterlibatan media di ruang media digital dan munculnya perusahaan berbasis digital seperti Google, Apple dan Microsoft dan lain-lain, sebagai penyedia konten media yang signifikan atau sebagai akses ke konten sosial yang dibuat pengguna.

3. Sosial - munculnya media sosial seperti Facebook, Twitter, dan YouTube yang mempromosikan penyebaran konten dan komunikasi peer-to-peer serta distribusi 
konten yang dibuat pengguna secara besarbesaran.

4. Tekstual — penggunaan kembali dan penggabungan ulang media ke dalam apa yang disebut model 'transmedia', di mana cerita dan konten media (misalnya suara, gambar, teks tertulis) tersebar di berbagai platform media.

Empat dimensi tersebut dapat ditambahkan dua elemen kunci lainnya yaitu :

1. Kebangkitan user created content, yang mana menggabungkan antara pembuat konten dan konsumen. Batasan antara pembuat konten professional dan konsumen media menjadi kabur.

2. Kebijakan konvergensi, karena aturan yang dibuat untuk jenis media yang sebelumnya sehingga harus dipertimbangkan kembali untuk bentuk konten dan media terkait.

Secara fisik newsroom mengalami perubahan hanya merupakan langkah awal sebuah strategi konvergensi. Domingo dalam Bradshaw ( 2018: 10) mengidentifikasi tiga lagi : professional yang multiskill, penyebaran dengan multiplatform, dan masyarakat yang aktif.

Lievrouw dan Livingstone dalam Flew (2014) telah mengamati bahwa setiap pendekatan tentang media baru, termasuk teori konvergensi digital, perlu memperhitungkan tiga elemen: 1 . artefak atau perangkat yang memungkinkan dan memperluas kemampuan kita untuk berkomunikasi 2. kegiatan komunikasi dan praktik yang dilakukan untuk mengembangkan dan menggunakan perangkat ini 3. pengaturan sosial dan organisasi yang terbentuk di sekitar perangkat dan praktik ini.

Flew (2014) merumuskan 20 konsep kunci media baru diantaranya: kecerdasan kolektif, konvergensi, industry kreatif, cyberspace/ realitas virtual, hak cipta digital, kesenjangan digital, ekonomi digital/ kapitalisme digital, globalisasi, peretasan, interaktivitas, pengetahuan ekonomi, mobile media, jaringan, partisipasi, pembajakan, rahasia pribadi dan pengawasan, remediasi, komputer di mana - mana, user created content, dan web 2.0.

\section{Digital Journalism}

Malik dan Shapiro dalam Franklin dan Eldridge II (2017) mengungkapkan Dua kata jurnalisme digital mengandung setidaknya dua definisi. Pertama, ide jurnalisme sebagai sesuatu yang berbeda dari berbagai sumber informasi alternatif tentang berita dan urusan publik menjadi semakin sulit untuk dijabarkan. Adapun ide digital, pasti harus mengacu pada lebih dari sekedar sarana di mana informasi disebarluaskan, karena halaman cetak dan berita siaran telah tersedia di platform digital selama beberapa tahun belakangan. Saat ini, penyebaran digital jurnalisme ada di mana-mana (Barthel, dalam 
Franklin dan Eldridge II), tetapi, untuk melampaui definisi teknologi semata, kami akan menggunakan eksplorasi kami dari berbagai ruang di mana kami secara intuitif mengenali jurnalisme 'digital' untuk mencatat fitur-fitur umum yang tampak untuk didefinisikan.

\section{Jaringan sosial}

Situs internet, yang pernah dianggap sebagai aset digital paling berharga organisasi berita, telah kehilangan reputasi karena orangorang beralih ke platform media sosial seperti Twitter, Facebook, dan Snapchat untuk tautan ke berita dan informasi (Thompson dalam Franklin dan Eldridhe II). Jaringan ini memungkinkan pembaca untuk menggunakan daftar, umpan, tag, dan perangkat lain untuk menyesuaikan informasi yang mereka terima dengan minat dan oleh influencer dan memungkinkan penerbit untuk mencapai langsung ke feed pengguna untuk memberikan informasi dari bunga yang dapat diprediksi (Evans, 2015; Shaw, 2015 dalam Franklin dan Eldridhe II ). Jurnalisme digital pada platform sosial memiliki potensi yang belum pernah terjadi sebelumnya untuk distribusi konten yang luas, karena pengguna tidak hanya berbagi informasi yang dikurasi dan direkomendasikan dalam jaringan pribadi dan global mereka, tetapi juga menggunakannya untuk berkomentar dan membagikan apa yang mereka ambil pada berita hari itu. Sebaliknya, wartawan sering memanfaatkan diskusi dan debat yang terjadi di jejaring sosial untuk mengambil perhatian audiens.

Dengan adanya media sosial, pola yang sama telah muncul. Rutinitas pengumpulan pesan dan sumber telah disesuaikan untuk memanfaatkan jangkauan media sosial untuk memperoleh cerita, saksi mata atau sumber informasi. Sudah menjadi hal yang biasa bagi para wartawan dan organisasi berita untuk menggunakan media sosial dan kemudian mempublikasikan apa yang mereka pilih sebagai bahan berita berdasarkan nilai-nilai berita yang sudah ada sejak lama. (Burgess, Marwick, Poell, 2018: 501)

Mobile web dan publikasi

Desain responsif memungkinkan situs web mengubah tata letak dan arsitektur tergantung pada perangkat pemirsa, tanpa mengubah konten yang tersedia. Namun, beberapa organisasi telah membuat publikasi berbasis web dan aplikasi yang unik untuk perangkat telepon genggam, memungkinkan konten jurnalisme berubah ketika berpindah antar platform.

\section{Aplikasi}

Cara lain pembaca dan pemirsa terlibat dengan jurnalisme digital adalah melalui aplikasi yang menggabungkan konten dan pemberitahuan pada perangkat seluler dan desktop (Weiss, 2013 dalam Franklin dan 
Eldridhe II). Aplikasi seperti Circa menawarkan kepada pembaca menulis ulang untuk mengembangkan cerita menggunakan beberapa sumber daring dan memberi tahu mereka tentang pembaruan apa pun untuk kisah yang mereka maksudkan.

\section{Komentar}

Seperti contoh sebelumnya, komentar tentang berita digital dan multimedia tidak terbatas pada situs web organisasi berita yang berasal. Percakapan dilakukan melalui jaringan media sosial dan publikasi dan aplikasi . Ketika menyangkut jurnalisme digital, potensi keterlibatan langsung tidak dapat diremehkan. Pengguna tidak hanya mengomentari berita dan multimedia, tetapi mereka dapat menunjukkan ketidakakuratan dan meberikan informasi yang lebih ahli dan konteks tambahan pada cerita.

Setelah mengidentifikasi di mana jurnalisme digital saat ini ditemukan, kita berada dalam posisi untuk mulai mengisolasi fitur yang ada hingga lahirnya internet. Meskipun tidak semua dari tujuh karakteristik berikut ini nyata atau signifikan dalam semua jurnalisme digital sepanjang waktu, kami berpendapat bahwa mereka semua dapat membuat perbedaan substantif terhadap konten dan dampak pekerjaan. Antara lain, jurnalisme digital di berbagai platform memiliki karakteristik sebagai berikut.

Interaktif
Hubungan antara penerbit digital dan konsumen adalah dua arah. Pembaca dapat menarik perhatian pada ketidakakuratan dan menawarkan keahlian mereka. Pada tahun 2010, The Guardian dan Washington Post meminta pembaca mereka untuk membantu mereka menganalisis, menginterpretasikan, dan memvisualisasikan informasi dari 90.000 dokumen rahasia yang dirilis secara publik oleh dokumen WikiLeaks (Chokshi, 2010). Organisasi berita yang didanai oleh banyak orang, seperti The Tyee di British Columbia, memungkinkan para pembaca untuk menyumbangkan uang untuk topik tertentu yang mereka ingin wartawan selidiki. Sebaliknya, alat analisis memungkinkan organisasi berita mengumpulkan banyak informasi tentang pemirsa dan kebiasaan menontonnya.

Dapat terus diperbaharui

Setiap karya jurnalisme dapat melalui banyak versi dan bentuk sebelum dipublikasikan, tetapi kemungkinan permutasi di masa depan yang membedakan digital. Setidaknya sejak pengeboman Kota Oklahoma pada 19 April 1995, yang telah digambarkan sebagai 'Hari Bastille jurnalistik' untuk "pembebasan surat kabar yang tiba-tiba dari batasan waktu yang terkait dengan cetak" (Zelizer dan Allan, 2010: 104-105), para jurnalis telah mendapatkan pengalaman dengan breaking news dengan sedikit informasi dibandingkan cerira yang lengkap. 
Blog langsung yang meliput acara yang sedang berlangsung, seperti audiensi publik atau uji coba, dapat terus diperbarui selama berbulan-bulan. Sebuah artikel yang dimulai sebagai laporan berita utama dapat ditulis ulang sepanjang hari untuk mencerminkan informasi baru yang ditemukan oleh pengarangnya ditambah koreksi, klarifikasi, dan penambahan pembaca.

\section{Sepanjang masa}

Jangka waktu potensial dari karya yang dipublikasikan secara digital dihitung dalam beberapa dekade atau abad versus harihari atau minggu-minggu berita analog. Dalam banyak kasus, informasi utama dan tautan secara otomatis dikirim ke Twitter dan disimpan ke arsip online, penelitian, dan kepemilikan. Dalam beberapa menit setelah kemunculannya yang pertama, sebuah berita akan di-tweet dan di-retweet dan diposting di newsfeeds Facebook. Terkadang pembaca akan membuat screen-grabs dari artikel yang sangat penting dan mengedarkannya. Sementara beberapa outlet berita, seperti BuzzFeed, menggunakan kode pelacakan untuk mengikuti konten mereka melalui berbagai jaringan, tetap ada potensi kuat untuk cerita untuk terus berjalan dan memiliki kehidupan mereka sendiri (Robischon, 2015 dalam Franklin dan Eldridhe II).

Global

Sama seperti jangkauan konten digital nampaknya praktis tak terbatas dalam waktu, begitu juga di ruang (duniawi). Bahkan jika berita dibuat untuk mencerminkan kepentingan lokal, berbagi melalui media sosial memberikannya kesempatan untuk didistribusikan secara terpisah dari platform dan sumber berita aslinya. Kedekatan geografis seseorang ke acara berita terkini tidak lagi menentukan berapa lama waktu yang diperlukan bagi mereka untuk menerima informasi. Media sosial dan peringatan berita, misalnya, memungkinkan imigran untuk mengikuti informasi real-time dari tanah air mereka melalui sumber-sumber di lapangan, daripada mengandalkan laporan koresponden asing.

\section{Pribadi}

Bahasa internet adalah percakapan; jurnalistik dengan unsur pribadi cenderung paling banyak dibaca. Mulai tahun 2006, kolom komentar The Guardian's Comment adalah area bebas yang mengundang penulis dari seluruh dunia untuk memposting kisah yang diedit tentang masalah saat ini; Huffington Post memungkinkan blogger untuk memposting gaya hidup dan cerita mengenai hubungan langsung ke situs. Wartawan berita juga dipengaruhi oleh pergeseran dari nada netral ke yang lebih akrab. Meskipun suara mereka pada umumnya masih diharapkan untuk lebih diredam dalam berita, penanaman persona digital memungkinkan mereka untuk secara selektif mengungkapkan dimensi lain dari 
kepribadian mereka. Misalnya, seorang reporter kejahatan dapat menulis berita langsung tentang penangkapan dramatis untuk situs web atau ponsel cerdas, tetapi di pos Twitternya, ia dapat melaporkan dari tempat kejadian dengan nada yang lebih banyak berbicara, menambahkan konteks saat peristiwa terungkap.

\section{Unsiloed}

Tidak untuk beberapa waktu, wartawan berita membutuhkan jurnalis sebagai penjaga gawang informasi (Bruns, 2005; Singer, 2014). Dengan tidak adanya hegemoni ini, organisasi media sekarang terhubung dengan pekerjaan pesaing dan sumber lain untuk membantu menawarkan pengalaman satu atap. Jurnalisme di era digital ada bersama dengan bentuk media lain, termasuk blog pribadi, tulisan advokasi, dan konten iklan. Penelusuran atas nama pemimpin dunia akan menghasilkan tautan ke sejumlah berita pendek bersama dengan tautan ke laman resminya, artikel Wikipedia, saluran YouTube-nya, dan umpan Twitter. Oleh karena itu, pengguna digital harus belajar bagaimana memfilter hasil seperti ini untuk berita aktual dibandingkan dengan propaganda yang disuarakan sendiri atau mungkin menyaring hanya berita dan informasi yang sesuai dengan keyakinan pribadi dan pandangan politik mereka.

John Pavlik dalam Ahva dan Steensen sejak jaringan media baru dapat bersifat interaktif, sesuai permintaan, dapat disesuaikan; sejak media baru dapat menggabungkan kombinasi teks, gambar, gambar bergerak dan suara baru; sejak media baru dapat membangun komunitas baru berdasarkan minat dan ketertarikan yang sama; dan sejak media baru memiliki ruang yang hampir tidak terbatas untuk menawarkan laporan yang mendalam, tekstur dan konteks laporan yang tidak mungkin pada media lainnya, media baru dapat mengubah jurnalisme.jurnalisme digital tidak lagi dilihat hanya sebagai sesuatu yang dibangun dalam struktur teknis, sosial, budaya, dan ekonomi; Hal ini dilihat sebagai domain yang perlu didekonstruksi agar kita memahami makna baru yang diperoleh jurnalisme dalam seluruh media digital.

\section{METODE}

Penelitian ini dilakukan dari tahun 2017 2018 dengan menggunakan metode studi kasus milik Robert E. Stake. Pengumpulan data dilakukan dengan proses wawancara dan obeservasi. Wawancara dilakukan dengan du acara, wawancara tatap muka dengan Yuvita Dhita (Supervisor Social Media Specialist NET.) dan wawancara melalui telepon dengan Ali Wahyoedi ( Head of NET Bali). Selalin itu proses observasi dilakukan di kantor NET. Jakarta, khususnya di ruang tim media sosial dan juga obervasi pada media digital milik NET. 


\section{Hasil dan Pembahasan}

Televisi digital

Sejak awal NET. dirancang dengan konsep digital atau pada masa itu akrab dengan sebutan new media. Departemen new media menjadi tonggak pengembangan digital platform. Tiga hal utama yang memegang peranan penting dalam kelancaran sistem digital atau pemanfaatan platform digital adalah tim, konten, dan peralatan. NET. memiliki tim yang memiliki kemampuan digital atau akrab dengan digital platform. Seperti penuturan Yuvita Dhita :

"Kita punya orang - orang yang memang mumpuni untuk bikin sistem semudah mungkin memindahkan tayangan on air ke tayangan digital."

Tim yang memiliki karakteristik hampir mirip dengan penonton digitalnya yaitu kaum milenial sehingga mampu menghasilkan produk digital yang baik. Tim yang mudah untuk beradaptasi dengan sesuatu yang baru terutama perubahan teknologi digital yang sangat cair atau cepat berubah. Pemahaman mengenai digital ini sudah merata hingga ke bagian biro daerah. Kekuatan tim ini juga dianggap menjadi penting bagi biro dalam mengelola konten digital agar tidak melanggar aturan contohnya kode etik jurnalistik.

Kalau konten -konten dari biro, jadi biro itu mereka juga punya digital aset masing - masing. pantauan dari departemen digital, itu karena mereka sudah sangat social media savy, itu memang kita kasih arahan. Kami pernah kumpul ngomongin social media itu dari departemen digital sama orang orang dari biro, sama teman - teman news yang di sini juga.

Ditambah lagi konten - konten yang dimunculkan secara on air juga selaras yaitu dengan konsep digital. Sehingga tidak sulit dalam menarik penonton digital ketika pindah menjadi tayangan digital. Termasuk pada konten beritanya. Diperkuat juga dengan kemajuan teknologi dalam menggunakan alat. Tak jarang tim NET. menggunakan kamera yang digunakan masyarakat sehari hari seperti kamera telepon genggam atau kamera DSLR. Kamera tersebut pun mampu menghasilkan tayangan dengan kualitas televisi yang baik. NET. juga memiliki fasilitas database sendiri yaitu NET.Connect. Aplikasi ini mampu mengidentifikasi karakteristik penonton NET. hal ini sangat membantu dalam mencapai target sasaran tuju informasi yang ingin disampaikan.

NET. juga memiliki ruangan khusus bagi tim digital dengan fasilitas komputer dan monitor besar. Dengan fasilitas ini tim mampu memantau perkembangan media sosial terkini, contohnya mengatahui kata kunci yang sedang ramai dibicarakan netizen. Atau bisa melihat tanggapan masyarakat dari informasi yang diunggah, bisa mendapat respon positif atau negatif. Dampaknya adalah NET. mampu mengatur strategi dalam mengunggah sesuatu di media sosial untuk 
mencapai tujuan. Salah satunya seperti ketika

NET. mendapat data bahwa sebuah peristiwa acara dari media lain menjadi trending, tim bisa melihat seberapa besar kemungkinan program atau tayangan mereka sendiri bisa menjadi trending juga. Jika tidak memungkinkan maka tim akan hanya mengupayakan bahwa agenda acara mereka menjadi bagian dari list peristiwa yang menjadi perhatian masyarakat.

Sejak tahun 2017 berganti nama menjadi divisi digital yang terdiri dari tiga unit yaitu channel management, unit product management serta unit content support. Masing - masing unit memiliki tanggung jawab tersendiri. Product management mengelola produk digitalnya seperti Zulu, NET-Z, NET connect dan NET CJ. Channel management terdiri dari dua sub unit yaitu media sosial dan media sosial specialist. Content support bertugas menunjang isi dari media sosial dan digital platform lainnya. Tim content support tediri dari videographer dan graphic design.

Fungsi Digital

Sejak dibentuk dan berubah nama dari new media menjadi tim digital, mereka memiliki fungsi kerja. Utamanya membangun tim digital dengan tiga fungsi yaitu public relation, marketing, dan promosi. Namun ternyata diranah lokal platform digital seperti pada media sosial memiliki fungsi lain yaitu fungsi penyiaran.

1. Fungsi Public relation (PR)
Dengan adanya sejumlah digital platform seperti media sosial yang baik diharapkan memberikan citra yang baik pula pada NET. citra interaktif dan ramah yang dibangun diharapkan mampu mendapatkan segmen yang diincar yaitu kaum milenial.

\section{Fungsi Marketing}

Digital platform milik NET. didorong untuk mendapatkan keuntungan. Sehingga NET. memiliki tiga medium yaitu off air, on air serta online. Sejauh ini baru media sosial YouTube yang murni memberikan keuntungan berupa uang sementara yang lainnya baru merupakan platform penunjang dari tim sales. Sesuai penuturan Yuvita Dhita:

\begin{abstract}
Jadi marketing yang aku maksud di sini udah pasti hubungann ya dengan revenue. Still it's a business. Jadi, hm... kita berusaha me-revenue dari digital-digital aset yang kita punya. Ada banyak macem sih tementemen sales marketing itu untuk jualan, cuma yang paling gampang misalnya dia lu spot ada di program apa, nanti benefitnya ke Twitter, mention atau segala macem. Terus udah banyak campaign-campaign yang integrated tuh, di on air ada, di off air ada, di online-nya ada, jadi fungsi marketing-nya jalan juga. Kaya tadi sempet aku sebut ada campaign BI goes to Campus, di off air-nya sekarang lagi ada workshop di Jogja, online-nya kita bangun awareness nih BI goes to Campus lewat social media aset yang NET punya. Terus juga secara Youtube kita punya revenue sendiri.
\end{abstract}

\section{Fungsi Promosi.}

Konten utama NET. adalah tayangan televisi sehingga semua platform diupayakan unt bisa mengarahkan masyarakat menyaksiskan acara tersebut. dengan karakteristik foto atau video 
dapat menginfomasikan berbagai hal. Meski visual yang ditampilkan harus menonjolkan jenis karakter tayangan, contohnya tayangan program 86 yang dikumpulkan adalah video menengangkan sementara program komdei seperti "ini talkshow" yang ditampilkanadalah visual ketawa.

\section{Fungsi Siaran}

Fungsi ini muncul bagi biro daerah. Sperti yang disampaikan Kepala Biro Bali, Ali Wahyodi. Ketika biro memiliki waktu yang terbatas dalam menyiarkan informasinya, seperti di Bali hanya setiap pukul 6-7 pagi. Sehingga pada setiap liputan yang diperoleh diupayakan akan tayang dalam format singak di media sosial Instagram dan format panjang di YouTube. Ditambah lagi terdapat 1 kawasan atau desa di Bali yang tidak dapat menerima siaran NET. karena masalah teknis padahal di daerah tersebut peristiwa yang terjadi lebih dinamis dan memiliki dukungan kontri. Sehingga sangat terbantu dengan adanya media sosial seperti YouTube dan Instagram. Ali Wahyoedi menuturkan:

"Kita konsisten kalau ini harus di publish karena slot jam tayang kita jam 6-7 pagi. Jadi kita coba bantu publish dengan media sosial. Kalau sistem ada timnya ada adminya ada bagian untuk editing, uploadnya."

\section{Ciri digital}

1. Interaktif

Ciri digital yang interaktif pun dilakukan oleh NET. sekaligus menguatkan fungsi PR atau humasnya. Yuvita Dhita menegaskan:

" nah, makanya semua akun social media tuh kita buat seinteraktif mungkin atau seramah mungkin, orang mau nanya kita usahakan untuk respon, jadi enggak one way"

Hal ini tidak mudah, karena tim digital mengupayakan jawaban yang berbeda dari setiap komentar atau pertanyaan yang muncul. Namun dampak yang muncul sangat luar biasa. Misalnya ketika netizen ( sebutan untuk masyrakat digital ) memberikan komentar yang menyudutkan terhadap tayangan NET., tanpa harus menjawab pun akan ada netizen lain yang membantu memberika klarifikasi. Yuvita Dhita mengungkapkan:

"misalnya nanya di Instagram "min ini
gimana ya? Ya udah kita jawabsaja
dan itu jawabannya ngga tamplate.
Memang isinya sama. Misalnya " bisa
jadi penonton di Ini Talkshow nggak?
Jawabannya memang bisa, tetapi
gimana caranya supaya orang - orang
itu mendapat jawaban yang
customize." 2. Penonton yang berbeda

NET. memiliki keyakinan penonton tekevisi berbeda dengan penonton platform digital. Contohnya mereka yang mengakses media sosial adalah mereka yang tidak memiliki waktu untuk menonton siaran televisi secara langsung secara penuh. Sehingga akun YouTube mengakomodir video - vodeo pendek dengan konten pilihan. 
Jika masyarakat ingin menyaksiskan tayangan ulang dari program siaran NET. difasilitasi dengan platform lain seperti ZULU. Sementara bagi masyarakat yang lebih gemar menyaksikan video singkat dari sebuah peristiwa terakomodasi dengan adanya tayangan media sosial seperti YouTube dan Instagram.

\section{Terus berubah}

Karakteristik platform digital yang mudah berubah terutama media sosial. Membuat NET. harus terus belajar secara mandiri atau mengikuti pelatihan yang kebanyakan merupakan undangan. Seperti Google yang banyak berbagi informasi mengenai fasilitas mereka yang bisa dimanfaatkan. Meski tim daerah belum secara keselurihan mendapatkan pelatihan pelatihan ini namun inisatif mandiri terus didorong agar menjadi kreatif. Misalnya mempelajari aplikasi yang memudahkan kerja tim ditambah harga gratis. Contohnya mengubah konten menjadi bentuk gift.

Selain itu, digital juga harus mampu mempelajari analitik, seperti google analytic, social media analytic. Untuk melihat respon yang diberikan masyarakat pada produk yang disebarluaskan. Seperti yang disampaikan Yuvita Dhita:

" masing -masing pemegang platform bertanggung jawab sama apa yang terjadi, konten apa yang mereka keluarkan, respon apa yang mereka dapat. Bahkan ketika suatu konten ternyata banyak angryny nih kita lihat, ya udah deh kita nggak usah keluarin konten yang kaya gini lagi. Angry yang mereka keluarkan lewat reaction di Facebook misalnya, itukan berpengaruh terhadap engagement. Engagement boleh tinggi, tapi kalau ternyata banyak angry, males juga dong kita terhadap suatu page. "

Dan semua ini dipelajari secara mandiri ditambah pelatihan yang kerap dilakukan baik dari pihak Google mau pun media sosial seperti YouTube. Guna memahami platform yang mereka sediakan dari sisi fitur maupun algoritmanya.

\section{Akses mudah, consumen is producer}

Artinya jika dulu saingan sebuah program acara adalah tayangan dari televisi lain, namun kini semua telah berubah. Kemajuan teknologi, kemudahan akses internet membuat siapa saja bisa menghasilkan karya dalam bentuk apa pun. NET. menyadari bahwa pesaingnya bukan lagi hanya soal rating progrsm tetapi pembuan konten lainnya.

\section{Visual}

Karaketistik digital yang sangat visual sehingga NET. mengharuskan produk media sosialnya kuat dengan visual. Meski begitu tetap harus mengikuti karakteristik masisng maisng media sosial. Misalnya dari durasi video untuk media sosial YouTube dan Instagram. Hingga mempertimbangkan agar masyarakat tidak perlu membayar kuota yang besar untuk mendapatkan informasi kita. 
Contohnya informasi visual pada media sosial lebih ringan menggunakan Gift. Hal ini disampaikan Yuvita Dhita.

Karena semakin sedikitnya times times orang di social media, itu sudah pasti harus ada visual. At least, mereka tertarik scrolling, berhentu, ngeliat konten kita. Kalau Instagram kan sudah pasti ada visual, tapi Instagram kan bisa mainin dari mana video, foto, instastory, live.

Namun begitu visual yang ditampilkan pun harus diperhatikan. Contohnya secara teknis ukuran foto yang diunggah untuk masing masing media sosial. Hal ini harus menjadi perhatian agar informasi yang disampaikan dapat diterima masyarakat dengan baik. Hal ini bisa dipelajari secara mandiri melalui artikel online.

\section{Informasi cepat tersebar}

Era digital seperti saat ini, kesalahan sekecil apa pun tidak dapat disepelekan. Jika dulu ada anggapan televisi yang bersifat selintas sehingga jika terjadi kesalahan tidak mungkin tersebar. Namun kini, masyarakat dengan mudah merekam kesalahan dan menyebarkannya hingga viral. Namun begitu informasi yang cepat beredar tersebut juga bisa memberikan efek positif ketika apa yang disebarkan merupakan informasi baik. Sehingga perusahan tersebut mendapatkan citra yang baik.

\section{Global}

Sifat intrenet yang mendunia berdampak pada penyebaran informasi yang juga turut menjangkau global. Hal ini diperkuat melalui contoh yang kerap muncul di Biro Bali. Meski peristiwa yang terjadi di daerah Bali tidak se menarik biro lainnya namun peristiwa yang disampikan dari Bali selalu menjadi perhatian dunia. Bahkan media sosial NET. Bali kerap menjadi acuan masyarakat luar untuk mengetahui informasi terkini. Salah satu contohnya saat peristiwa letusan Gunung Agung.

\section{On Demand}

Pemanfaatan platform digital membuat masyarakat dapat memilih informasi yang yang ingin dikonsumsi sesuai dengan peminatannya. Baik melalui website, aplikasi mau pun media sosial seperti YouTube, Instagram, Facebook.

\section{PEMBAHASAN}

Flew (2014) mengungkapkan salah satu cara memahami transformasi digital dari media baru adalah melalui konsep konvergensi.

In that respect, definitions of media convergence as involving the combination of the three $\mathrm{Cs}$ of computing (digital media and information technologies), communication (networks, artefacts and practices) and content (media and information), as used by Barr (2000), as well as in earlier definitions of this book 
(such as Flew 2002) may be more useful.

Jika Flew menegaskan tiga hal yang berkaitan dengan makna konsep konvergensi dalam memahami transformasi digital yaitu komputer, komunikasi dan isi. Hal ini sejalan dengan situasi di NET. yang menunjukkan tiga hal utama menopang perkembangan tim digital mereka. Tiga hal tersebut adalah tim, konten dan peralatan. Peralatan sejalan dengan konsep computing yang mana sejak awal NET. berdiri sudah dirancang sebagai televisi digital. Wisnu Utama selaku pendiri NET. menegaskan sifat digital pada televisi ini baik kualitas siaran mau pun pemanfaatan platform. peralatan digital yang digunakan juga menunjukkan karakter digital journalist di dalamnya.

Seperti pemanfaatan kamera perangkat gawai dalam memproduksi dan menyebarkan informasi. contohnya saat melaporkan peristiwa berkaitan dengan erupsi Gunung Agung secara live pada akun media sosial Instagram dan Facebook. Hal ini sejalan dengan perkembangan digital atau social media journalism secara Global. Seperti yang dilakukan CNN, Telegraph, USA Today, CBS News, Al- Jazeera. Newman menungkapkan tren live menggunakan media sosial muncul sejak tahun 2017 ketika Facebook dan Instagram mengembangkan fasilitas siaran langsung tersebut.
Live news video has been around for more than two decades but exploded in the last year with the birth of Facebook Live. Such is Facebook's obsession with live video, they paid the world's top publishers to produce content for the platform, shelling out $\$ 50 \mathrm{~m}$ to Buzzfeed, the New York Times and the BBC amongst others. Instagram introduced live streaming in 2016 while Twitter added 360 degree live video within Periscope and has made live streaming a core audience and revenue focus for the company. Meanwhile SnapChat has had success with its 24 hour Live Stories, crowdsourced collections of digital media from a specific location.

Jika berkunjung ke ruangan tim digital NET. kita akan melihat bagaimana tim ini memantau dunia digital melalui sistem yang sudah dibangun bersama tim TI. Sehingga tim digital dengan mudah membaca topik apa saja yang sedang dibahas secara global. Serta juga bisa memantu akun media sosial dari pesaing. Pihak lawan di sini bukan hanya akun media sosial milik televisi lain tetapi bisa bersifat personal yaitu contohnya adalah akun milik YouTuber lain. Konsep communication berkaitan dengan tim yang ada di NET.. Televisi ini memiliki tim yang akrab dengan digital dan mudah beradaptasi dengan perkembangan teknologi yang terus berubah. Akun media sosial program televisi baik produksi mau pun tim news serta tim biro dikelola oleh masing - masing tim. Contohnya seperti yang terjadi di Biro Bali, 
penggunaan media sosial saat peliputan atau pun distribusi berita dibebaskan kepada tim. Sejauh ini hasilnya, tim mengembangkan kreativitas agar laporan menggunakan media sosial digemari masyarakat terutama kaum muda. Namun nyatanya mengelola media sosial tidak lah gampang. Biro Bali mengakui bahwa digital baiknya dikelola dengan jumlah tim yang memadai. Contohnya saat peristiwa Gunung Agung Bali, Biro Bali masih sanggup melakukan siaran langsung melalui akun media sosial. Namun kini karena keterbatasan tim, pemanfaatan tool pada media sosial pun terbatas.

Konsep content menurut Flew juga sejalan dengan konten yang dimiliki NET.. Program acara yang NET. miliki sejalan dengan karakteristik digital yang akrab dengan kaum muda. Ditambah lagi karakteristik visual yang terdapat pada konten digitalnya. Bradshaw (2018 : 111) bahwa terdapat beberapa strategi yang dapat membantu konten berita menjadi menonjol di media sosial. diantaranya adalah visual merupakan kunci. Yang dipertegas dengan riset oleh Rogers dalam Bradshaw menunjukkan sebuah berita yang diunggah dengan tambahan visual pada media sosial twitter meningkatkan kemungkinan di retweet sebesar 27 persen.

Dengan tim yang cukup memadai, memudahkan NET. untuk menyebarkan informasi pada platform digital seperti website, media sosial dan aplikasi sesuai dengan karakteristiknya masing - masing. contohnya media sosial Instagram yang kuat dengan visual pendek. Sehingga video yang ditayangkan harus dipilih agar mampu menarik perhatian masyarakat. Sementara akun media sosial YouTube bisa memberikan tayangan lebih panjang. Untuk tayangan berita akan diunggah per masing - masing item berita. Sementara untuk tayangan produksi atau program secara kesuluruhan dapat diakses melalui NET Zulu.

Meski dalam proses produksi, digital journalist bisa menggunakan peralatan seperti telepon genggam dengan kualitas yang tidak kalah dengan kamera profesional. Namun NET. perlu memperhatikan hasil akhir dari informasi tersebut. Terutama mengingat pola konsumsi masyarkat yang kini lebih didominasi menggunakan gawai mereka dalam mendapatkan informasi. Newman (2017), seluler menjadi saluran yang paling penting untuk berita, lebih banyak penerbit yang menyadari pentingnya menciptakan lebih banyak lansiran yang relevan bagi pengguna ponsel cerdas untuk menarik orang kembali ke aplikasi dan situs web.

Meski dikelola masing - masing program, namun tim digital turut dapat memberikan laporan atau evaluasi terkait tanggapan masyarakat pada sebuah berita. Terutama terkait etika dalam informasi berita. Meski bersifat sangat cepat namun informasi 
yang disebarkan melalui media sosial harus tetap memperhitungkan kodek etik jurnalistik.

Malik dan Shapiro dalam Franklin dan Eldridge II (2017) mengungkapkan sejumlah ciri digital journalism diantaranya: Jaringan sosial, mobile web dan publikasi, aplikasi, komentar. Jaringan sosial berarti bahwa dalam proses pencarian berita masyarakat mulai beralih pada platform media sosial. Hal ini sudah dipahami sejak NET. didirikan pada tahun 2013 yang mana pendirinya yaitu Wisnu Utama sudah menegaskan pendirian televisi digital. Selain itu jaringan sosial bermakna masyarkat dapat menggunakan berbagai fitur pada media sosial untuk mencari informasi yang diinginkan. Contohnya menggunakan fitur pencarian tagar pada media sosial Instagram atau pun Twitter. Tak hanya mencari, masyarakat juga bisa membagikan informasi dan memberikan rekomendasi terhadap informas tersebuti.

Sejalan dengan data yang menunjukkan angka pencari informasi menggunakan telepon genggam dan melalui media sosial yang terus meningkat. Mobile web dan aplikasi menjadi platform yang populer saat ini. menurut Newman sejumlah media bereksperimen menemukan karakteristik dari infromasi visualnya.

BuzzFeed and Vice have already built large businesses in helping brands integrate messages into videos, and with marketing budgets shifting towards content expect other publishers to focus more on these lucrative feature-based opportunities in 2017. Great Big Stories, from CNN, is an attempt to engage younger audiences with uplifting substantive stories for the smart and curious distributed through digital channels. Bloomberg has also been experimenting with longer form video such as Hello World, a technology travel series hosted by Businessweek technology reporter Ashley Vance.32 The show will eventually work on television but is made in segments that can be cut up and shared on Facebook, YouTube and Snapchat. The Economist has expanded its fi lms unit to focus on non-fi nance subjects like travel, social affairs, tech, and culture. What all these examples have in common is that the featurebased subjects make them more suitable for sponsorship and native advertising than traditional news.

Hal ini tampaknya, perlu juga dilakukan NET. dalam membangun ciri visualnya sehingga mudah dikenali masyarakat. Tak hanya itu, yang terutama adalah menggunggah informasi sesuai dengan karakteristin platform masing- masing melalui perangkat gawai. Sehingga bukan hanya memotong tayangan berita lalu kemudian ditayangan di media sosial. Tetapi secara khusus membuat produk digital untuk perangkat gawai.

Kolom komentar juga menjadi ciri platform digital. Dalam hal ini NET. berupaya untuk membangun interaksi yang bersifat personal dengan masyarakat. Sekaligus dalam upaya membangun jaringan yang lebih luas. 
Ciri ini bersifat personal artinya NET. tidak ingin memberikan jawaban yang bersifat template. Terutama pada pertanyaan pertanyaan yang sifatnya berulang. Seperti cara menjadi penonton pada sebuah program. Manfaat dari fitur ini sangat dirasakan ketika NET. mendapat komentar yang kurang baik terhadap suatau tayangan tertentu. Contohnya pada tayangan program 86, yang mendapatkan komentar karena menayangkan visual yang dianggap kurang pantas oleh masyarkat. Tanpa harus memberikan komentar balasan, karena biasanya netizen lain terlebih dahulu membantu dengan memberikan jawaban atau klarifikasi. Bradshaw (2018: 283), dalam sisi komunikasi intreaktivitas berarti membuka kesempatan masyarakat untuk berkomunikasi dengan media dan jurnalisnya. Yang bermakna komunikasi dua arah.

Selain empat fitur sebelumnya Malik dan Shapiro dalam Franklin dan Eldridge II juga membedakan karakteristik khusus, yaitu interaktif, belum selesai, sepanjang masa dan global. Belum selesai dan sepanjang masa terkait sifat internet yang mampu menyimpan informasi atau berita selamanya dan juga dapat diperbaharui. Serupa dengan karakteristik yang mendunia, informasi yang diunggah di internet dapat diakses dari mana pun selama ada akses internet.

\section{KESIMPULAN}

Tim digital NET. secara maksimal telah memanfaatkan platform digital seperti media sosial, aplikasi dan website. Penggunaan platform tersebut dapat berdiri atas nama perusahan secara keseluruhan, atas nama program acara, atas nama biro atau atas nama produk. Dalam pengelolaanya pun tidak semua dipegang oleh tim digital. Sebagian besar dikelola masing - masing meski masih dalam pengawasan tim digital. Contohnya tim digital dapat memberikan saran setelah membaca perkembangan digital seacra global mau pun di Indonesia.

Tiga pilar utama yang dimiliki NET. dalam mengembangkan platform digital yaitu tim yang akrab dengan digital, teknologi yang terus dijangkau, dan konten yang sesuai dengan segmentasi digitalnya.

Tim digital ini memiliki fungsi public relation (kehumasan), fungsi marketing, fungsi promosi dan fungsi siaran. Melalui platform ini diharapkan citra televisi NET. tetap terbangun dengan baik. Fungsi marketing, yaitu untuk turut memperoleh keuntungan melalui sejumlah platform yang dikelola. Sejauh ini akum media sosial YouTube yang telah memperoleh Gold Button YouTube. Fungsi Promosi, yaitu tetap berdasar pada platform utamanya yaitu program televisi, diharapkan digital dapat membantu mempromosikan program tersebut. Fungsi 
siaran ditemukan pada Biro dengan durasi siaran yang terbatas seperti contohnya pada Biro Bali yang memiliki waktu saiaran dari pukul 6- 7 WIT. Ditambah lagi tidak semua wilayah Bali mendapat siaran NET. dengan baik.

Sejumlah karakateristik digital media dan digital journalist juga sudah jelas terlihat. Meski perlu sejumlah penguatan seperti ciri video media sosial yang perlu ditonjolkan. Serta produksi video untuk konsumsi melalui perangkat gawai. Tim digital NET. tetap menyadari sifat digital yang terus berubah. Sehingga setiap bagian dalam tim ini harus terus belajar secara mandiri mau pun melalui fasilitas perusahaan.

\section{DAFTAR PUSTAKA}

Adornato, Anthony. (2018). Mobile and Social Media Journalism. A Practical Guide. SAGE Publications. United Kingdom.

Asosiasi Penyelenggara Jasa Internet. (2017). Infografis Penetrasi \& Perilaku Pengguna Internet Indonesia 2016. (2018).

Infografis Penetrasi \& Perilaku Pengguna Internet Indonesia 2017.

Burum, Ivo dan Quinn, Stephen. (2016). Mojo: The Mobile Journalism
Handbook. How to Make Broadcast Videos with an iPhone or iPad. Focal Press Burlington.

Bradshaw, Paul (2018). THE ONLINE JOURNALISM HANDBOOK. Skills to Survive and Thrive in the Digital Age $2^{\text {nd }}$. Routledge. Abingdon.

Burgess, Jean, dkk. 2018. The SAGE Handbook of Social Media. SAGE Publication. London

Clark, Lynn Schofield dan Marchi, Regina. (2017). Young People and The Future of News. Social Media and the Rise of Connective Journalism. Cambrige University Press. USA.

Flew, Terry. (2014). New Media $4^{\text {th }}$ edition. Oxford University Press. Australia.

Franklin, Bob dan Eldridge II, Scott A. (2017). The Routledge Companion to Digital Journalism Studies. Routledge. Abingdon.

Mayangsari, K., Krisdinanto, N., dan Purnama, F. Y. (2014). Implementasi Share dan Rating Sebagai Dasar Kebijakan Pemrograman Yuk Keep Smile (YKS) Trans TV. Jurnal Komunikatif, Universitas Katolik Widya Mandala Surabaya.Vol.3/ No.2, (112-137) 
Newman, Nic. 2017. Digital News Project 2017. Journalism, Media, and Technology Trends and Predictions 2017. Reuters Institute. England.
Newman, Nic. 2018. Digital News Project 2018.Journalism, Media, and Technology Trends and Predictions 2018. Reuters Institute. England.

Thurman, Neil dan Walters, Anna. 2012. Digital Journalism. Routledge. 